$\left.2 k^{6}\right)^{5} 168$ RFP-1078

\begin{abstract}
(2)
\end{abstract}

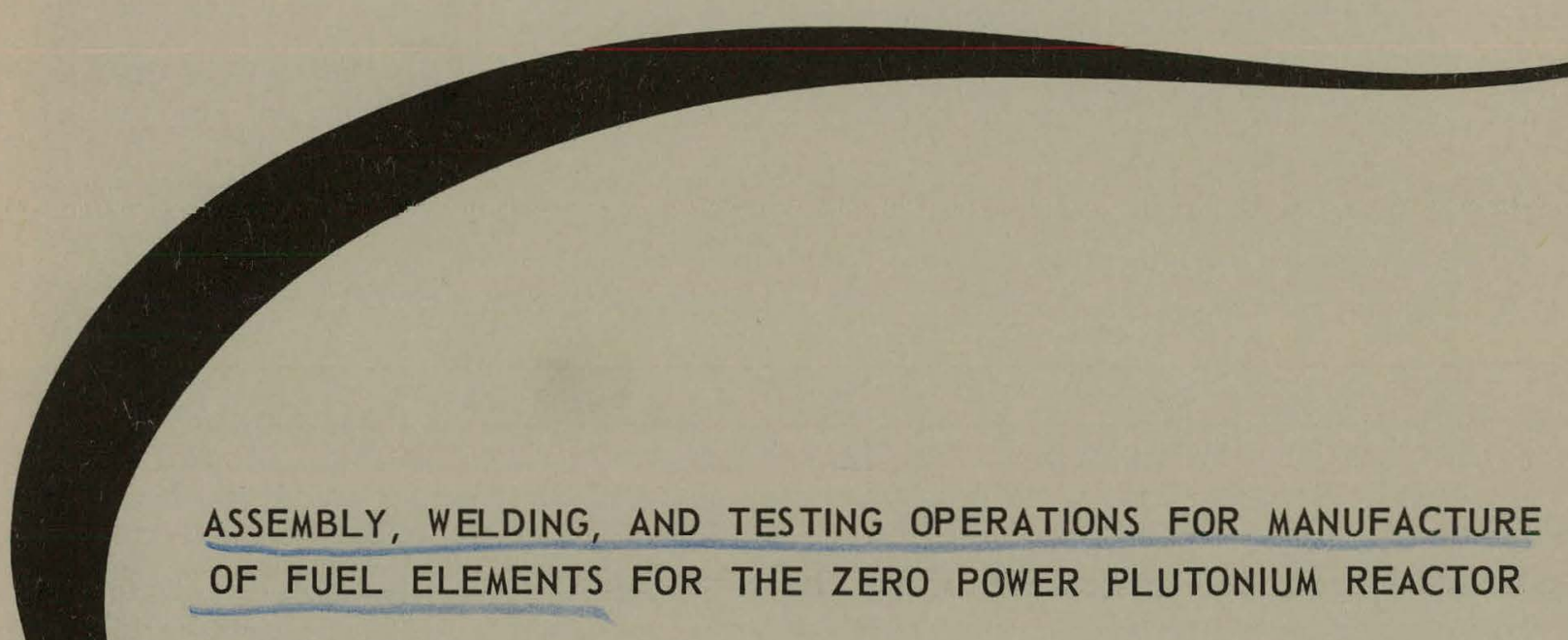

ASSEMBLY, WELDING, AND TESTING OPERATIONS FOR MANUFACTURE OF FUEL ELEMENTS FOR THE ZERO POWER PLUTONIUM REACTOR

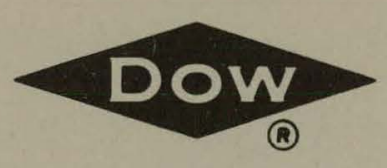

THE DOW CHEMICAL COMPANY

ROCKY FLATS DIVISION

P. O. BOX 888

GOLDEN, COLORADO 80401

U.S. ATOMIC ENERGY COMMISSION

CONTRACT AT(29-1)-1106 


\section{DISCLAIMER}

This report was prepared as an account of work sponsored by an agency of the United States Government. Neither the United States Government nor any agency Thereof, nor any of their employees, makes any warranty, express or implied, or assumes any legal liability or responsibility for the accuracy, completeness, or usefulness of any information, apparatus, product, or process disclosed, or represents that its use would not infringe privately owned rights. Reference herein to any specific commercial product, process, or service by trade name, trademark, manufacturer, or otherwise does not necessarily constitute or imply its endorsement, recommendation, or favoring by the United States Government or any agency thereof. The views and opinions of authors expressed herein do not necessarily state or reflect those of the United States Government or any agency thereof. 


\section{DISCLAIMER}

Portions of this document may be illegible in electronic image products. Images are produced from the best available original document. 


\section{LEG AL NOTICE}

This report was prepared as an account of Government sponsored work. Neither the United States, nor the Commission, nor any person acting on behalf of the Commission:

A. Makes any warranty or representation, expressed or implied, with respect to the accuracy, completeness, or usefulness of the information contained in this report, or that the use of any information, apparatus, method, or process disclosed in this report may not infringe privately owned rights; or

B. Assumes any liabilities with respect to the use of, or for damages resulting from the use of any information, apparatus, method, or process disclosed in this report.

As used in the above, "person acting on behalf of the Commission" includes any employee or contractor of the Commission, or employee of such contractor, to the extent that such employee or contractor of the Commission, or employee of such contractor prepares, disseminates, or provides access to, any information pursuant to his employment or contract with the Commission, or his employment with such contractor.

Printed in the United States of America

Available from

Clearinghouse for Federal Sclentific and Technical Information National Bureau of Standards, U. S. Department of Commerce

Springfield, Virginia 22151

Price: Printed Copy $\$ 3.00$; Microfiche $\$ 0.65$ 


\title{
ASSEMBLY, WELDING, AND TESTING OPERATIONS FOR MANUFACTURE OF FUEL ELEMENTS FOR THE ZERO POWER PLUTONIUM REACTOR
}

\author{
S. Siemion \\ D. F. Livesay
}

\section{LEGAL NOTICE}

Thls report was prepared as an account of Government sponsored work. Nelther the United - States, nor the Commission, nor any person acting on behalf of the Commission:

A. Makes any warranty or representation, expressed or $1 \mathrm{mpll}$ ed, with respect to the accuracy, completeness, or usefulness of the information contalned in this report, or that the use of any information, apparatus, method, or process disclosed in this report may not infringe privately owned rigbts; or

B. Assumes any liabilitles with respect to the use of, or for damages resulting from the B. Assumes any liabilites with respect to the use of, or for damages resuld
of any information, apparatus, method, or process disclosed in thls report.

As used in the sbove, "person acting on behalf of the Commisalon" includes any emAs used in the sbove, "person acting on behalf of the Commisalon" Includes any em-
per or contractor of the Commission, or employee of such contractor, to the extent that ployee or contractor of the Commission, or employee of such contractor, to the extent that
such employee or contractor of the Commission, or employee of such contractor prepares, disseminates, or provides access to, any information pursuant to hls employment or contract with the Commission, or his employment with such contractor.

\author{
THE DOW CHEMICAL COMPANY \\ ROCKY FLATS DIVISION \\ P. O. BOX 888 \\ GOLDEN, COLORADO 80401
}

U. S. ATOMIC ENERGY COMMISSION

CONTRACT AT(29.1)-1106 


\section{CONTENTS}

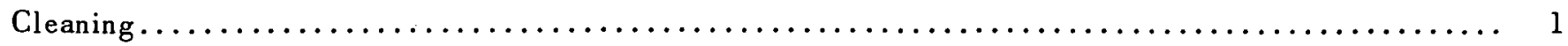

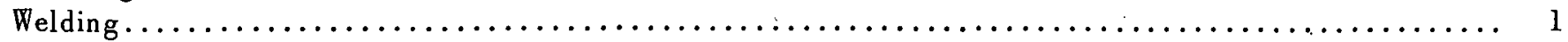

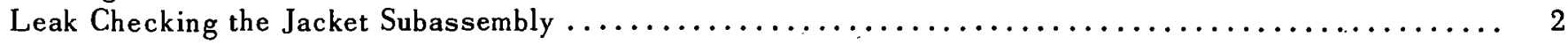

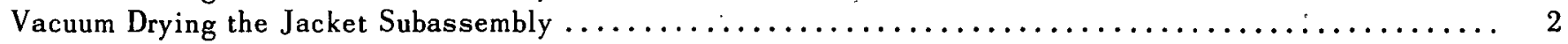

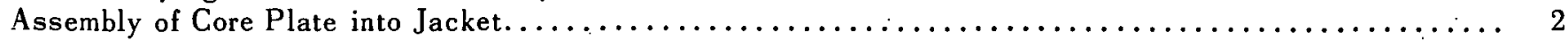

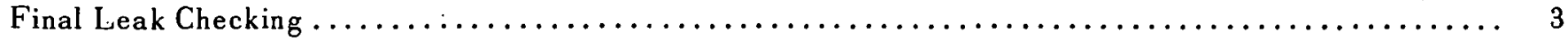

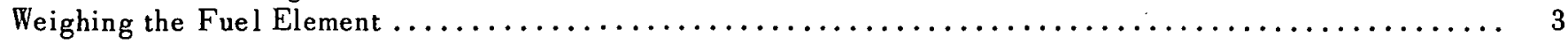

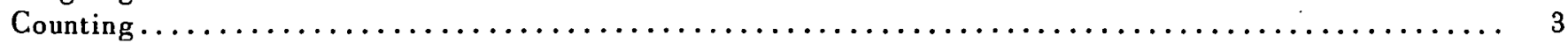

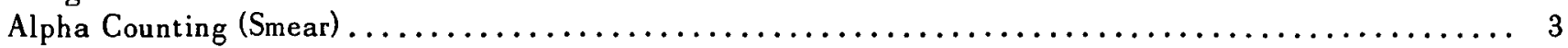

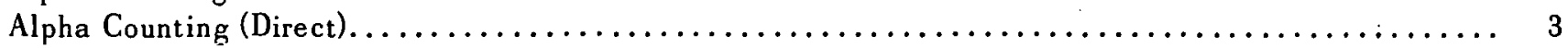

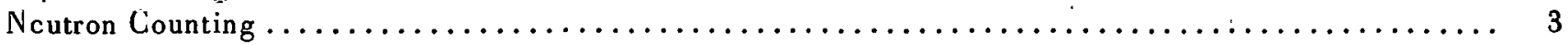

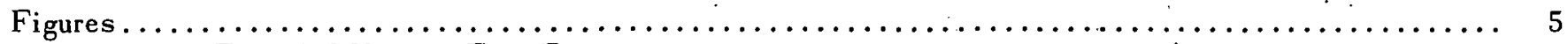

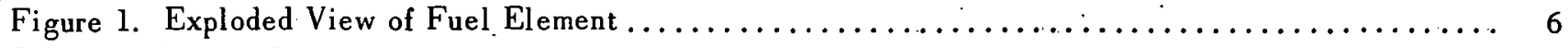

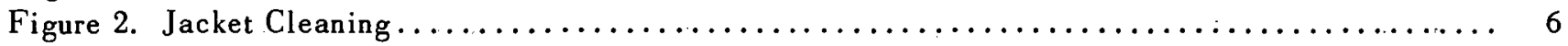

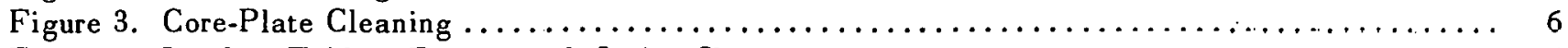

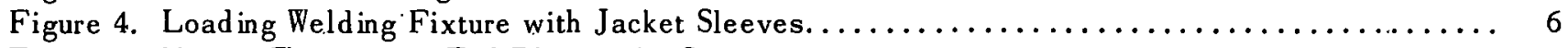

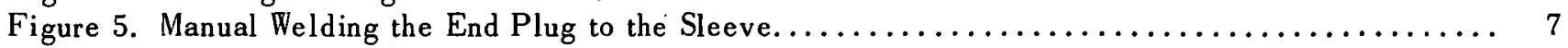

Figure 6. Machine Weld ing of Jacket Subassemblies. $\ldots \ldots \ldots \ldots \ldots \ldots \ldots \ldots \ldots \ldots \ldots \ldots \ldots \ldots \ldots$

Figure 7. Machine Welding of Jacket Subassemblies. $\ldots \ldots \ldots \ldots \ldots \ldots \ldots \ldots \ldots \ldots \ldots \ldots \ldots \ldots$

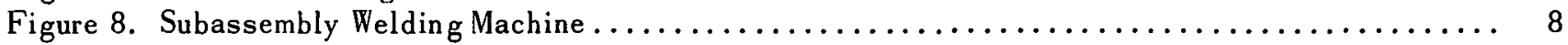

Figure 9. Final Closure Welding in Argon-Helium Filled Chamber $\ldots \ldots \ldots \ldots \ldots \ldots \ldots \ldots \ldots \ldots \ldots, 8$

Figure 10. Chamber for Reduced Pressure Welding $\ldots \ldots \ldots \ldots \ldots \ldots \ldots \ldots \ldots \ldots \ldots \ldots \ldots \ldots \ldots$

Figure 11. Typical Photomicrograph of Weld Sections $\ldots \ldots \ldots \ldots \ldots \ldots \ldots \ldots \ldots \ldots \ldots \ldots \ldots \ldots$

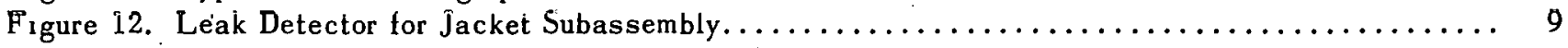

Figure 13. The Vacuum Chamber for Drying Jacket-Subassemblies $\ldots \ldots \ldots \ldots \ldots \ldots \ldots \ldots \ldots \ldots \ldots$.

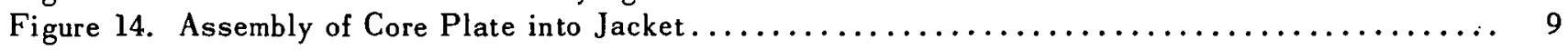

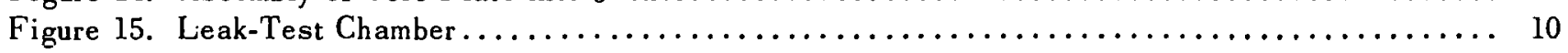

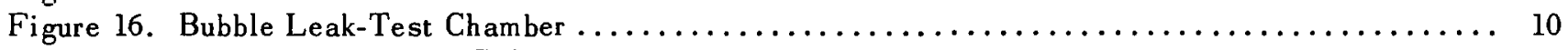

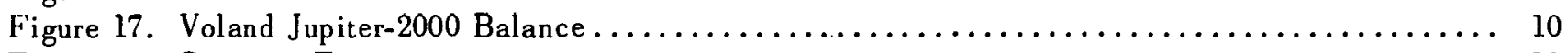

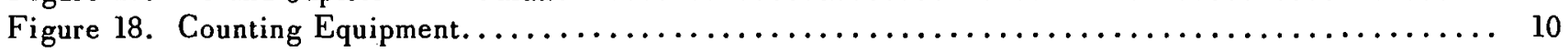




\title{
Assembly, Welding, and Testing Operations for Manufacture of Fuel Elements for the Zero Power Plutonium Reactor
}

\author{
S. Siemion and D. F. Livesay
}

The ZPPR fuel element is a solid, rectangular, sixsided, uranium-plutonium-molybdenum core plate encased in a stainless steel jacket. The fuel element is made in five sizes. All elements are 2.00 inches wide by 0.250 -inch thick; they vary in length from 4.00 inches to 8.00 inches. Figure 1 is an exploded view of the 7.PPR fuel e.lement.

Each jacket consists of a jacket sleeve and two endplugs. The end plugs are identical and the sleeves differ in length only for the different sized elements. The jacket sleeve wall is 0.015 -inch thick and the end plugs are 0.100 -inch thick. Both are fabricated from type $304 \mathrm{~L}$ stainless steel.

The work described here is of the assembly, welding, and testing operations performed in the manufacture of the ZPPR fuel elements.

Cleaning: The stainless steel jackets and end-plugs are cleaned by ultrasonic vapor degreasing in Alk-Tri ( a trichloroethylene solvent, for a minimum of 4 minutes (Figure 2). Specifications require that the trichloroethylene be sampled for analysis. The solvent can be used for cleaning if: (1) the water content is less than $200 . \mathrm{ppm},(2)$ the residue content is less than 0.05 grams per liter, and (3) the $\mathrm{pH}$ is greater than 10.0 .

The solvent is changed when (1) no more than 20 jackets and 40 end plugs per gallon of solvent have been cleaned, (2) when no more than 20 jacket subassemblies (jacket with one end-plug welded in) have been cleaned, or (3) when the solvent becomes visibly dirty. After the parts are cleaned, they are handled with lint-free, clean, cotton gloves, and wrapped in clean aluminum foil.

The core plate is cleaned by securing it in a vacuumcup holder and by bringing all surfaces in contact with a fixed, rotating, stainless steel wire-brush (Figure 3). The powdered residues remaining on the surfaces are then removed by wiping with clean cheese-cloth.

(H) Trademark of The Dow Chemical Company.
Welding: The fuel element is welded in two operations using the inert-gas shielded tungsten arc welding process. In the first operation, an end plug is.welded into the jacket sleeve to make the jacket subassembly. The second operation is performed after the core plate and second end-plug have been assembled into the jacket subassembly. Separate welding fixtures are utilized for each welding operation and each of these fixtures will hold five parts.

The welding fixtures for each operation differ only in the way the parts are held in the fixtures. The fixtures consist of machined aluminum frames with copper chills that are designed to contact all four sides of each jacket sleeve. Also copper clamps are positioned on top of each end plug.

In the first welding operation, a gage block is utilized with the fixture to position the jacket sleeve in the fixture and to locate a positioning gage within the sleeve. The positioning gage is used to locate and align the end plug within the jacket sleeve. The welding fixture is loaded with sleeves when it is inverted and resting on the gage block (Figure 4). The gage block positions the end of the sleeve 0.033 inch above the top surface of the fixture and positions the end of the positioning gage within 0.067 inch of the end of the sleeve. After the sleeves and positioning gages are locked into the fixture, the end plugs are then inserted in to the sleeves. This leaves the end plugs protruding 0.033 inch above the end of the sleeves.

The copper clamps that contact the tops of the end plugs are positioned to within 0.030 inch of the edge of the plug and expose the ends and one long side for welding. After these seams are welded, then the clamps are installed on the opposite side of the fixture and the other long seams are welded. The short welds at the ends of the plugs are manually welded to the sleeve (Figure 5), and then the fixture is transferred to a welding machine where the long sides of the sleeves are machine-welded to the end plugs (Figure 6 and 7 ). The welding machine (Figure 8 ) consists of a movable base that supports and traverses the weld fixture beneath a stationary welding torch. The base is moved in the $X$ direction with a lead screw driven by $a$ variable speed gear motor. 'l'he torch holder is equipped 
with a cross slide for motorized adjustment in the $Y$ and $\mathrm{Z}$ directions and micrometer adjustments in the $\mathrm{X}$ and $\mathrm{Y}$ directions.

When the ends are manually welded, the current is controlled at approximately 36 amperes by a footoperated potentiometer. The shielding gas flow is 17 cfh argon and $7 \mathrm{cfh}$ helium. The procedure is to weld across the end and around the corners. This ensures that the side welds will tie in properly at the corners.

The welds on the sides of the jackets are made with the following parameters:

$\begin{array}{ll}\text { Current } & 36 \pm 2 \text { amperes } \\ \text { Voltage } & 9 \text { volts } \\ \text { Travel speed } & 3.0 \pm 0.2 \mathrm{ipm} \\ \text { Gas flow } & 17 \mathrm{cfh} \text { argon }-7 \mathrm{cfh} \text { helium } \\ \text { Clectrode } & 0.060 \mathrm{in} . \text { diameter } 2 \% \text { thoriated } \\ & \text { tungsten } \\ \text { Electrode spacing } & \begin{array}{l}\text { Electrode tip } 0.025 \mathrm{in} . \text { from side } \\ \text { of end plug and } 0.065 \mathrm{in} . \text { above } \\ \text { fixture }\end{array}\end{array}$

The machine welds are started and stopped on copper run-off tabs that are placed at both ends of each joint.

For the second welding operation, there are requirements that there be 40 -pounds clamping force between the end plugs and the core while the end and side welds are being made. Also it is required that the assembled and welded fuel element shall be filled with argonhelium gas at a pressure of 5 to 7.5 psia.

The welding fixture for this operation is similar to the fixture used for welding the subassemblies. The copper chills are identical and the same amount of the jacket sleeve and end plug is exposed for welding. The requirement that the end plugs be forced against the core plate is met by clamping the elements against spring loaded plungers that exert a 40 -pound upward force against the bottom of the fuel element.

The short welds at the ends and one side of the long welds are made using the same welding equipment as used on the subassemblies. The final closing welds are made at sub-atmospheric pressure in a chamber that can be evacuated and back filled with an argonhelium gas mixture. The procedure is to first place the welding fixture in an airlock on the chamber prior to its movement into the welding chamber. The airlock is evacuated to 20 microns and backfilled with a $70 \%$ argon-30\% helium gas mixture. The welding chamber is equipped with a welding machine, power supply, and controls that are identical to those used for welding the subassemblies. Before these welds are made, the chamber is evacuated to a pressure of less than 200 microns for a period of 5 minutes or more. The chamber is then filled with a $70 \%$ argon $-30 \%$ helium gas mixture to a pressure of 6 psia and then the final welds are made at this pressure (Figure 9). The same welding parameters that are used at atmospheric pressure are used for the reduced pressure welding. Strip-chart recordings of the amperage are made during the closure welding to determine any variance in the operation which would cause a sub-standard weld (Figures 10 and 11).

After welding, the length of the fuel element is not to exceed the length of the core plus the thickness of the end plugs plus 0.003 inch. Also the end plugs must be square and parallel with the jacket-sleeve sides within 0.003 inch.

Leak Checking the Jacket Subassembly: After the first end-plug is assembled and welded into the jacket, the welded joint is leak checked. (F'igure 12 shows how the helium is introduced inside the jacket.) If a leak exists, the helium is drawn through the leak into the helium-sensitive, Mass Spectrometer leak detector, and the leak rate is recorded.

Vacuum Drying the Jacket Subassembly: After the jacket subassemblies have been proven leak tight, and cleaned again as described under Cleaning, they are dried under vacuum and stored in this environment until they are needed for assembly (Figure 13). The 6-inch, high varumm system ronsists of a merhaniral pump, a Roots blower, and a cold trap. Ultimate pressure for this system is about $1.0 \times 10^{-6}$ torr. All items are handled with lint-free, clean cotton gloves in this operation, and are wrapped in clean aluminum foil on removal.

Assembly of Core Plate into Jacket: After the core plate is cleaned and weighed, it is assembled into a jacket subassembly (Figure 14). The core plate is passed into the jacket subassembly through a fixt.ure. mounted in the drybox window of Plexiglas. To avoid radioactive contamination of the jacket mouth, a $0.001-i n c h$ thick stainless steel funnel is mounted into the fixture. The mouth of the jacket subassembly is guided over the funnel so that when the core plate is inserted into the jacket only the inside of the funnel becomes contaminated. After the core plate is inserted into the jacket, the subassembly is removed from the fixture, and then the end plug is inserted. The second end-plug is then welded as described earlier. 
Final Leak Checking: The fuel elements are first subjected to an exterior helium pressure of $80 \mathrm{psig}$ for 3 minutes, to force helium through any leaks which may exist in the sealed jackets. A stream of compressed air is then passed over the assemblies to remove any trace of helium from the outside surfaces. The fuel elements are immediately placed into the leak-check chamber (Figure 15). The leak rate is recorded by a helium-sensitive Mass Spectrometer leak detector, which is sensitive to a leak of $<1.0 \times 10^{-10} \mathrm{cc} / \mathrm{sec}$ stp. If the elements appear leak tight, they are again pressurized to $80 \mathrm{psig}$ and placed into the bubble leak-test chamber filled with water (Figure 16). The pressure in the chamber is reduced to 12 to 15 inches $\mathrm{Hg}$ using a mechanical vacuum pump. This leak . check is primarily for gross leaks which could allow the the helium to be removed during pumpdown, prior to the helium leak-check.

Weighing the Fuel Element: All fuel elements are weighed to the nearest one-tenth of a milligram on a Voland Jupiter-2000 analytical balance (Figure 17).

Counting: All fuel elements are counted to determine neutron-count rates, and total alpha contamination.

ALPHA COUNTING (SMEAR) - This alpha count is made to determine the amount of removable contamination on the fuel element case. A piece of filter paper moistened with ethyl alcohol is used to wipe all surfaces. After the filter paper is allowed to dry, it is placed in a multi-channel alpha scintillation counter, and a 10 minute count of the contamination adhering to it is made. If the disintegrations per minute (dpm) are 10 or less, it is acceptable.
ALPHA COUNTING (DIRECT) - This alpha count is made to determine the amount of contamination imbedded in the surface of the fuel element case. The fuel element is placed in a holder and then both are placed into the counter (Figure 18), and counted for 5 minutes. The alpha contamination specification is less than 500 disintegrations per minute. The fuel elements are subjected to two of these counts at a 3-day interval. The edges and ends of the fuel elements are then counted with a portable alpha counter to make certain that no one surface shall exceed 200 disintegrations per minute.

NEUTRON COUNTING - Again, using the same holder and counting geometry shown in Figure 18, the fuel elements are subjected to a neutron count. The neutron specification is $140 \%$ of value calculated for spontaneous neutron yield.

\section{REFERENCES}

1. Argonne National Laboratory Specification No. PF-1600, Specification for Uranium-PlutoniumMolybdenum Alloy ZPPR Fuel Elements, January 27, 1967.

2. Argonne National Laboratory Specification No. PF-1613, Specification for ZPPR Fuel Element Jacket Components, January 27, 1967.

3. ANL-7313, A. B. Shuck, H. F. Jelinek, A. G. Hins, N. J. Carson, Jr., A. A. Denst and T. A. Steele, The Development of a Design and Fabrication Method for Plutonium-Bearing Zero-Power Reactor Fuel Elements. 
RFP-1078 
RFP-1078

\section{Figures}




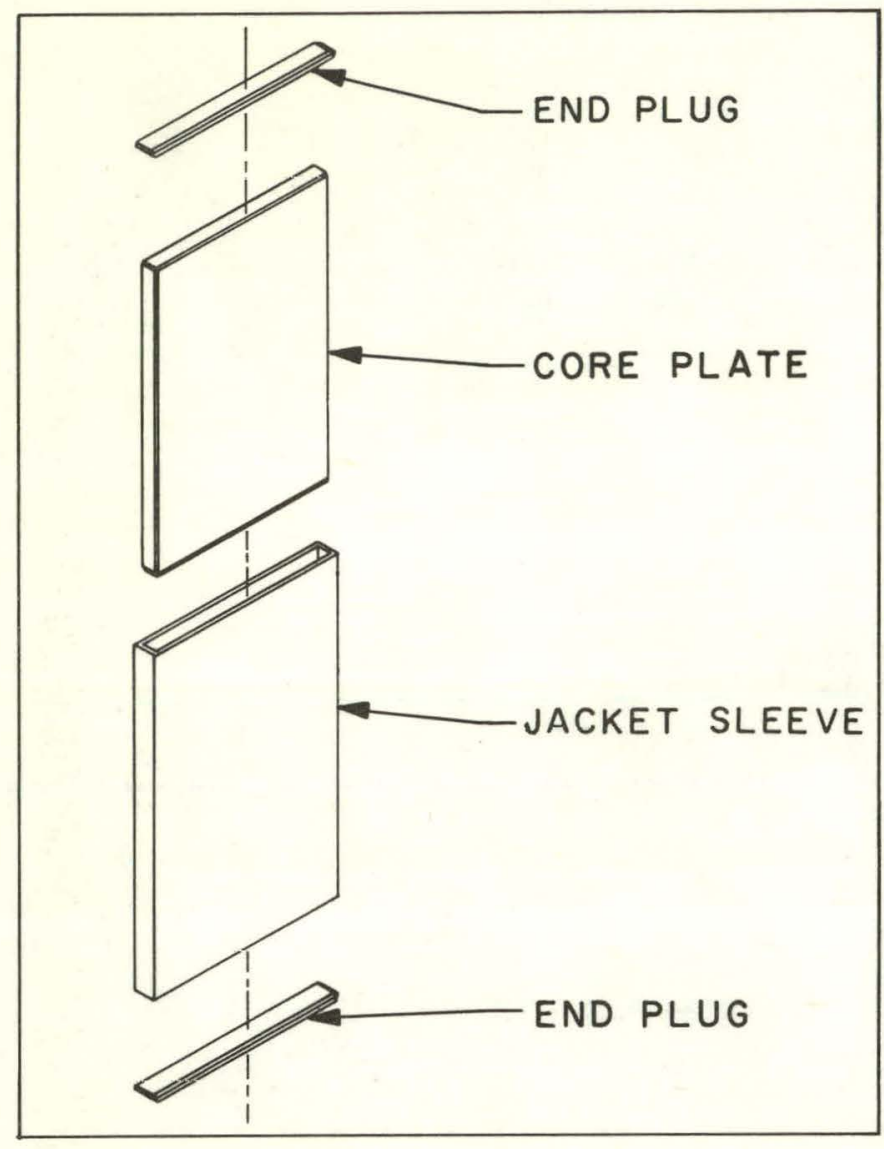

FIGURE 1. Exploded View of Fuel Element.

FIGURE 2, Jacket Cleaning.

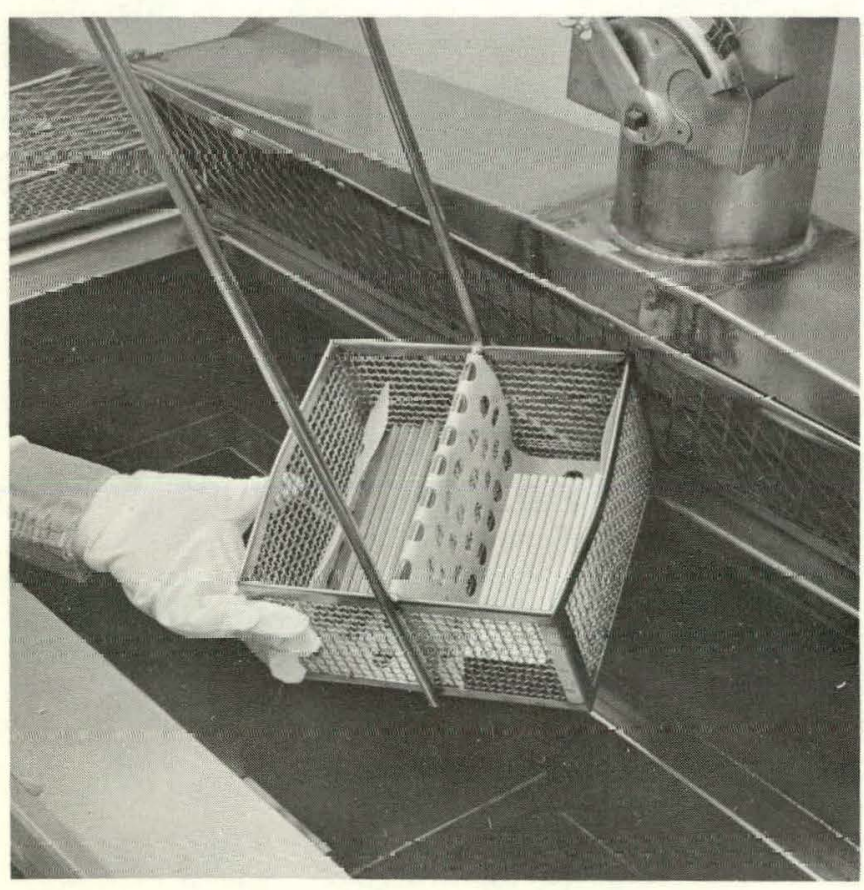

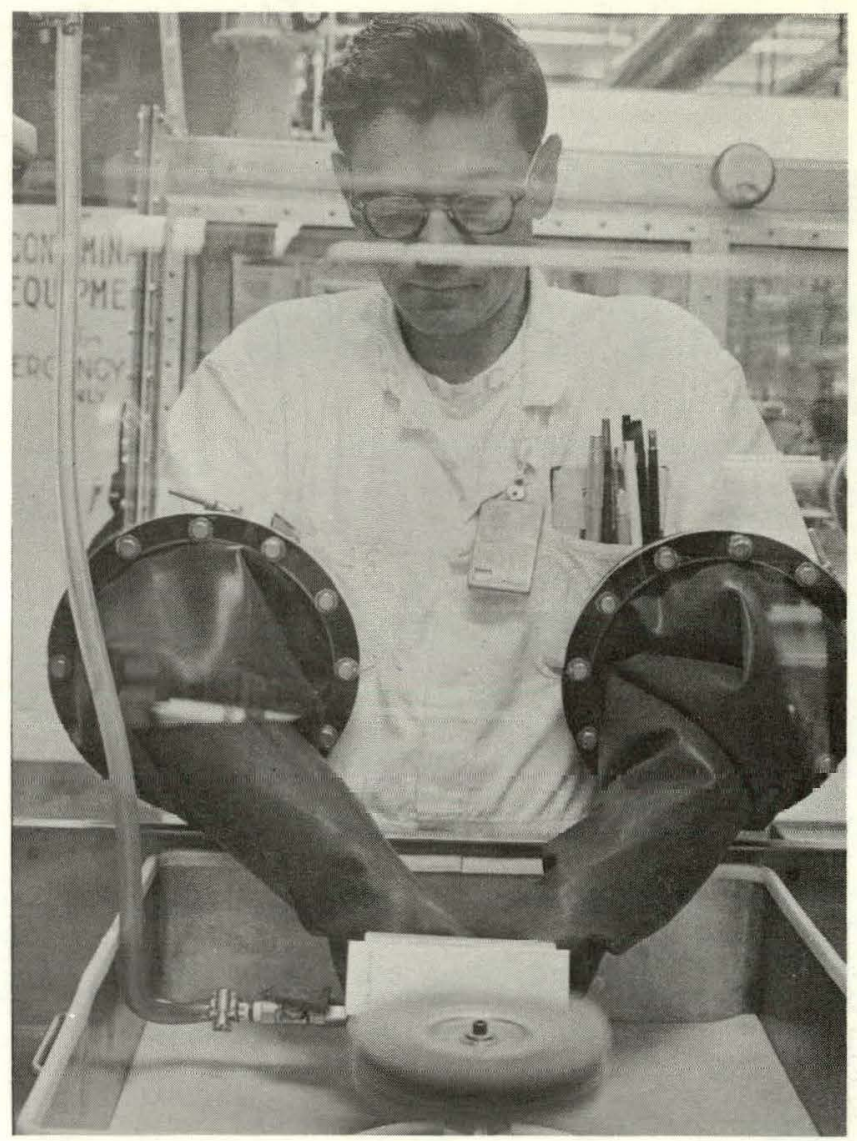

FIGURE 3. Core-Plate Cleaning.

FIGURE 4. Loading Welding Fixture with Jacket Sleeves.

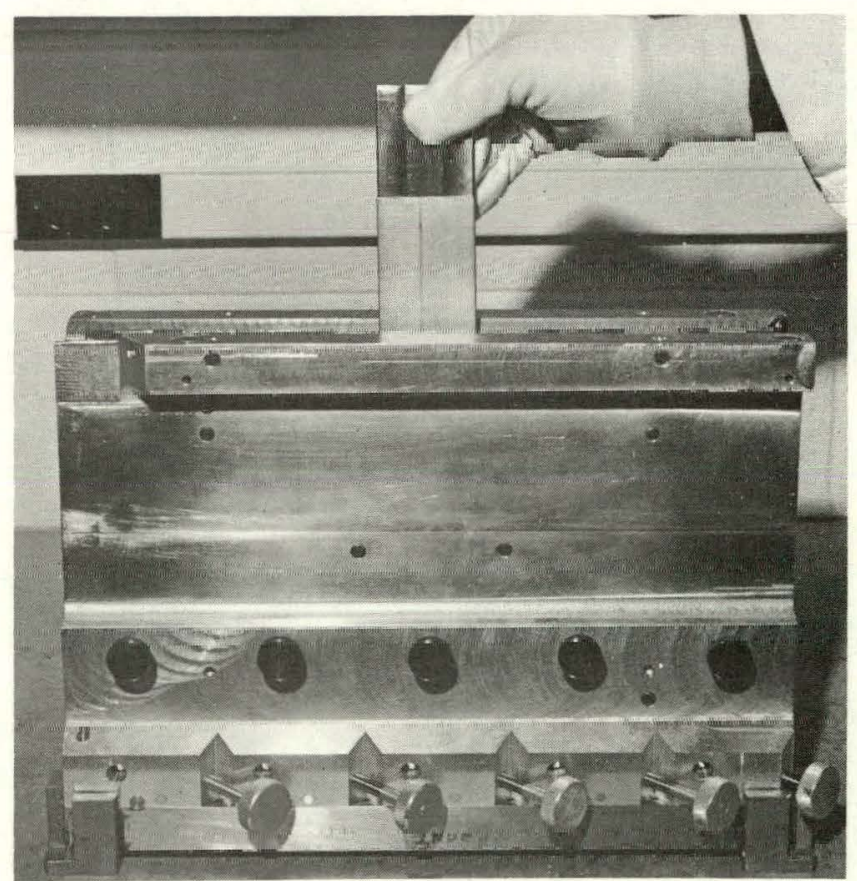




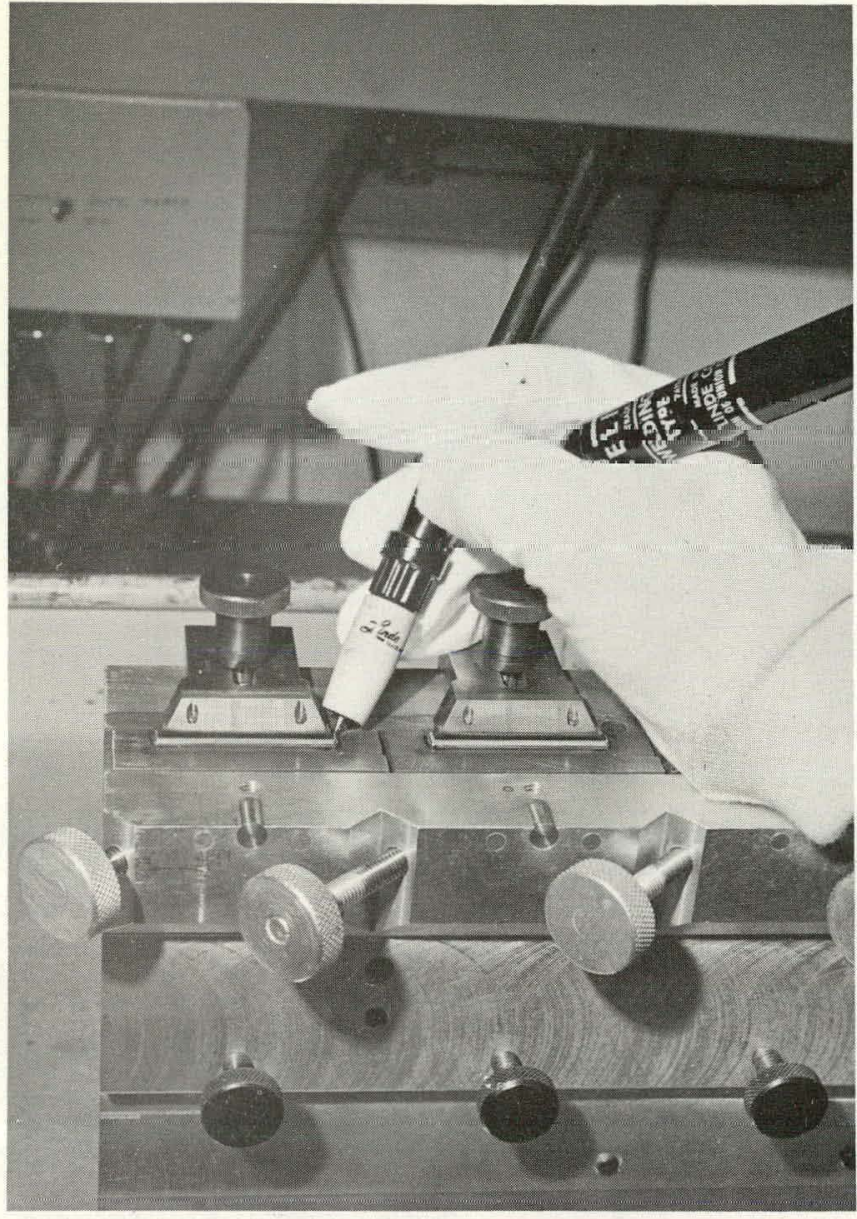

FIGURE 5. Manual Welding the End Plug to the Sleeve.

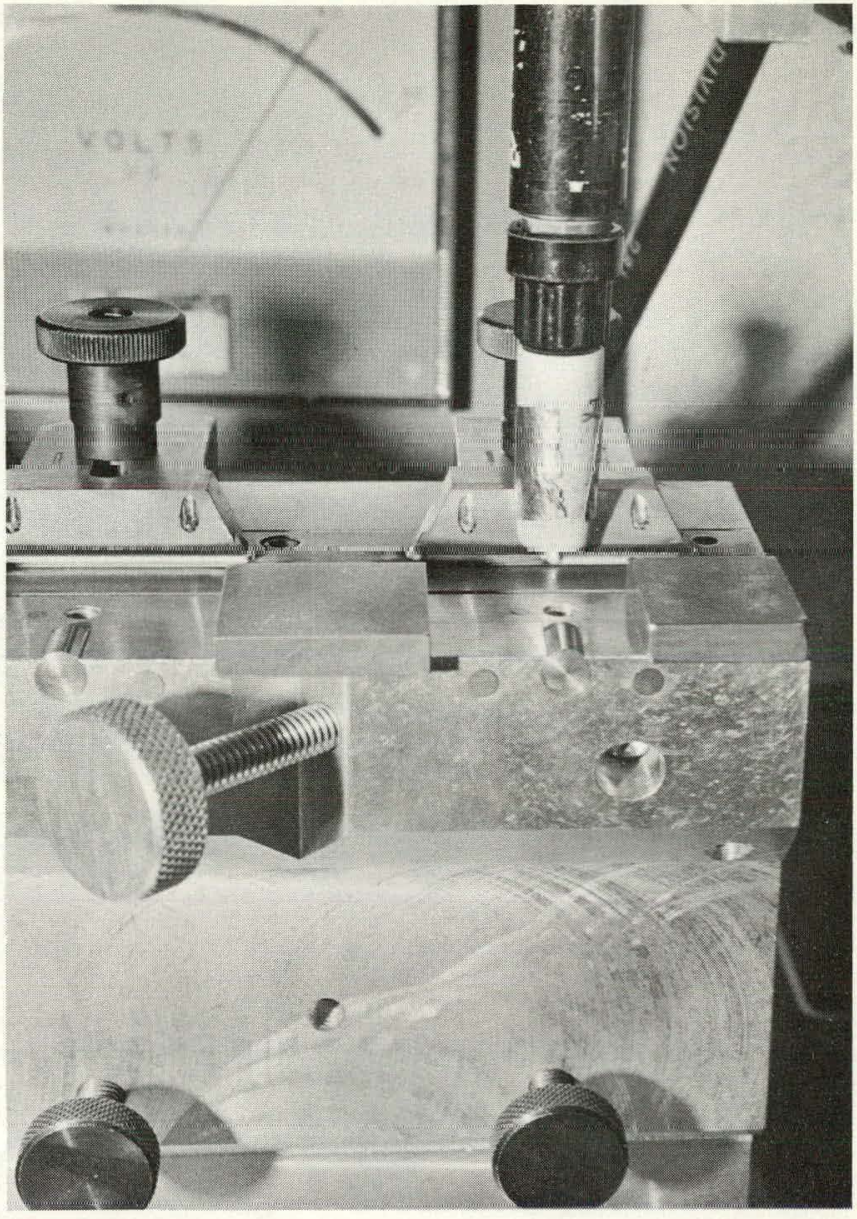

FIGURE 6. Machine Welding of Jacket Subassemblies.

FIGURE 8. Subassembly Welding Machine.

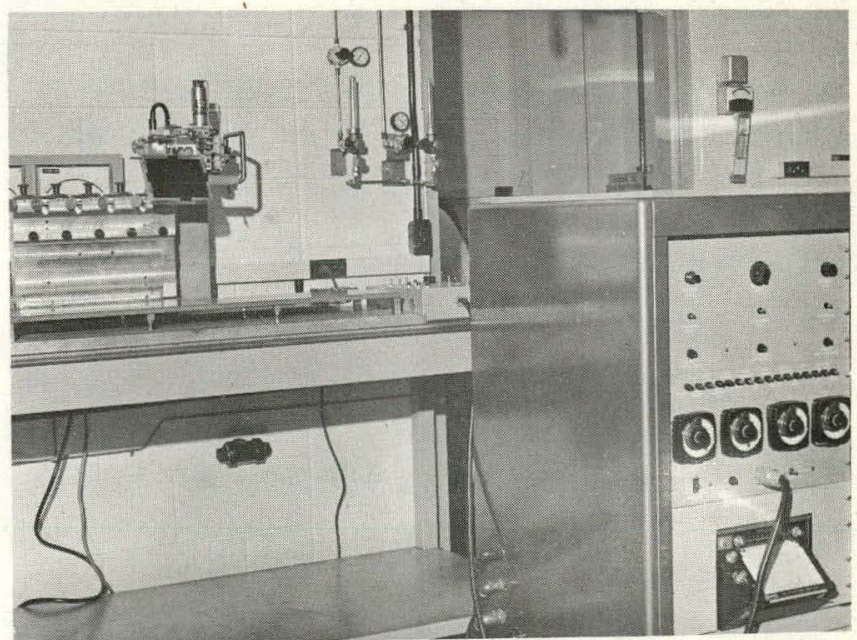




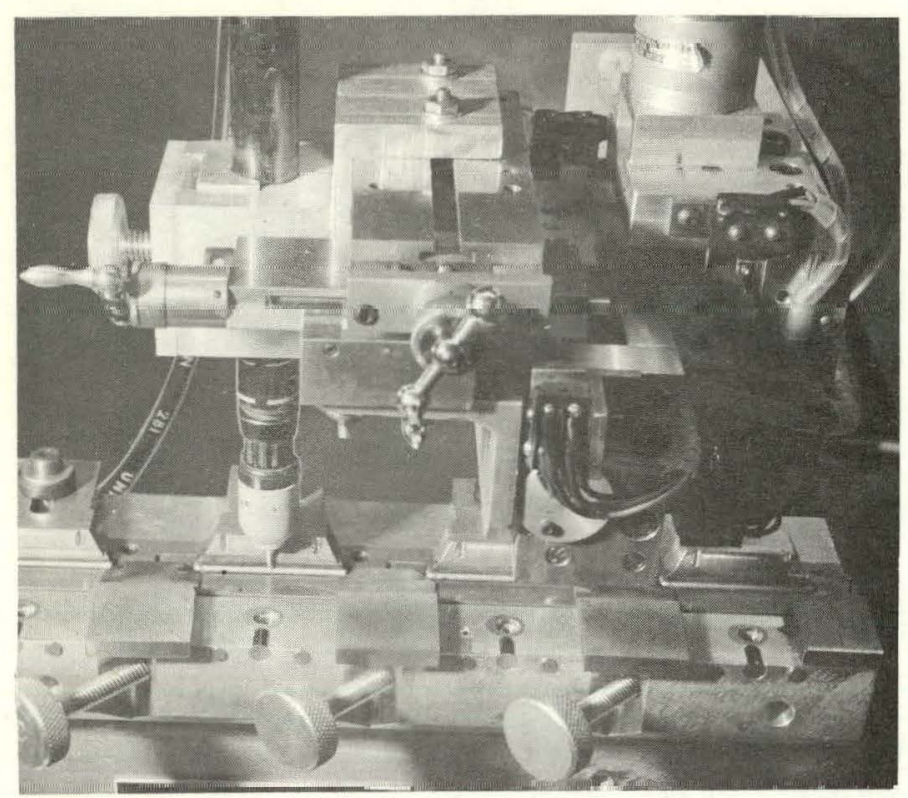

FIGURE 9. Final Closure Welding in Argon-Helium Filled Chamber.

FIGURE 10. Chamber for Reduced Pressure Welding.
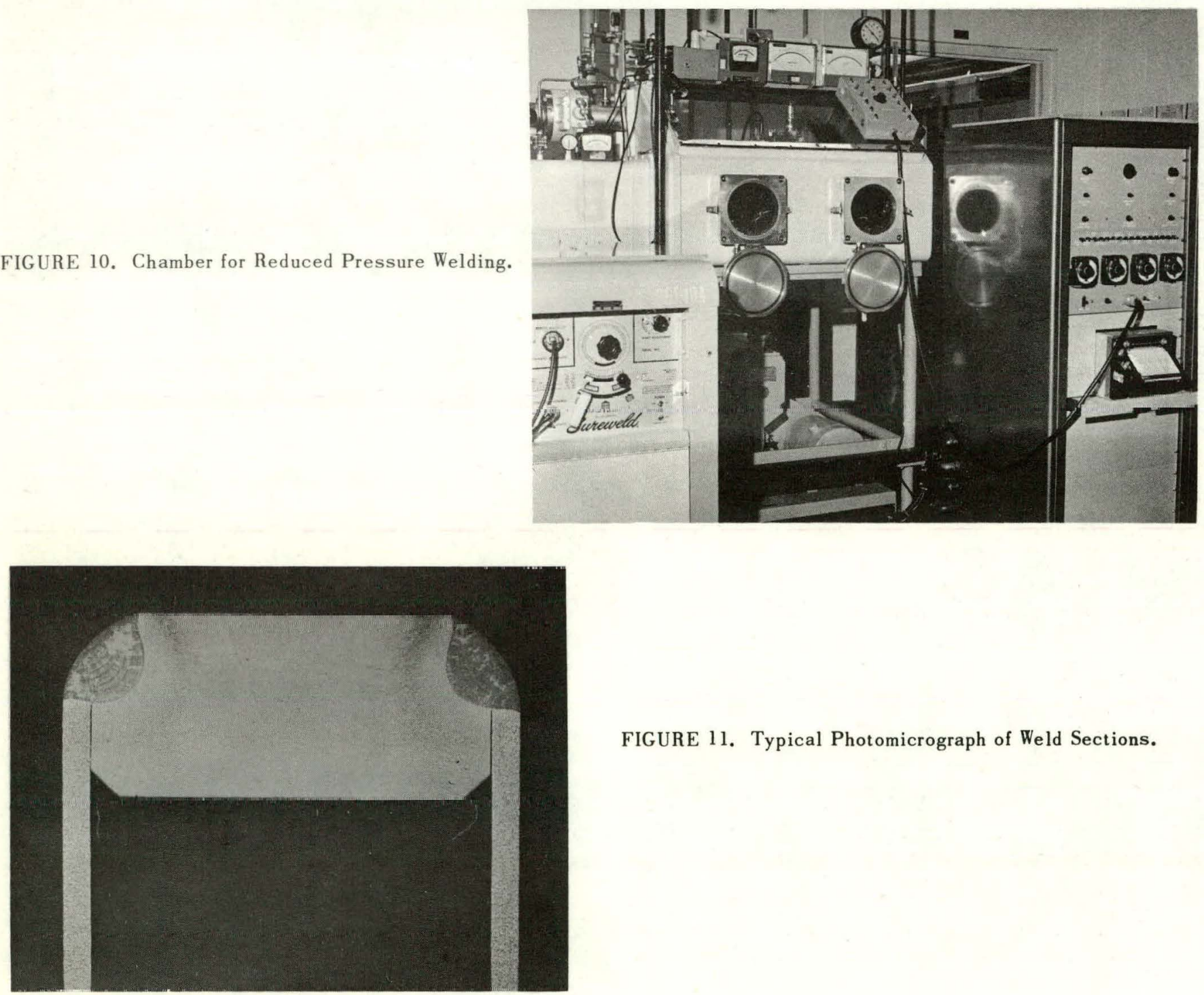

FIGURE 11. Typical Photomicrograph of Weld Sections. 
FIGURE 12. Leak Detector for Jacket Subassembly.
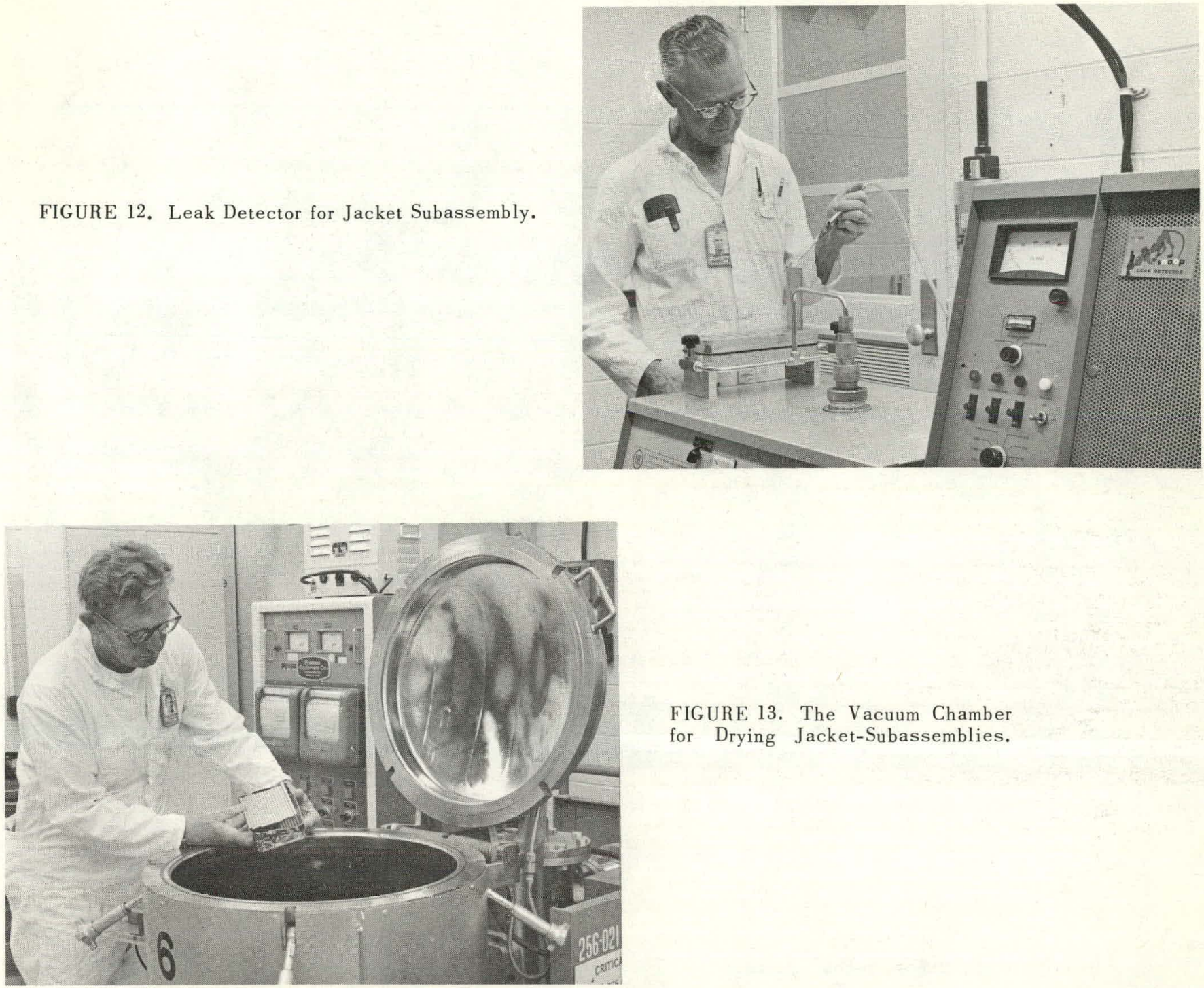

FIGURE 13. The Vacuum Chamber for Drying Jacket-Subassemblies.

FIGURE 14. Assembly of Core Plate into Jacket.

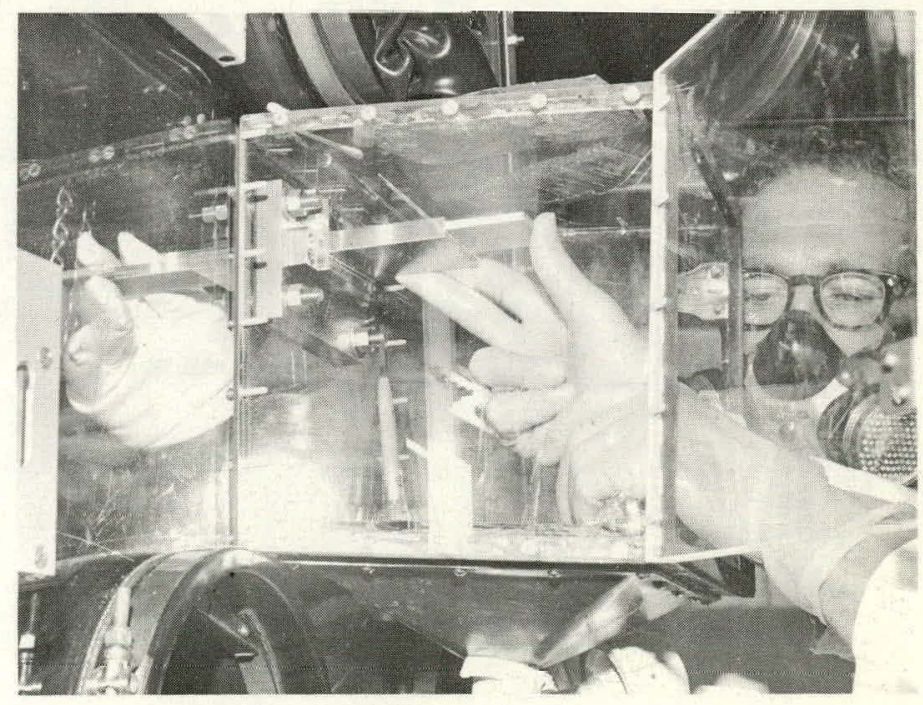




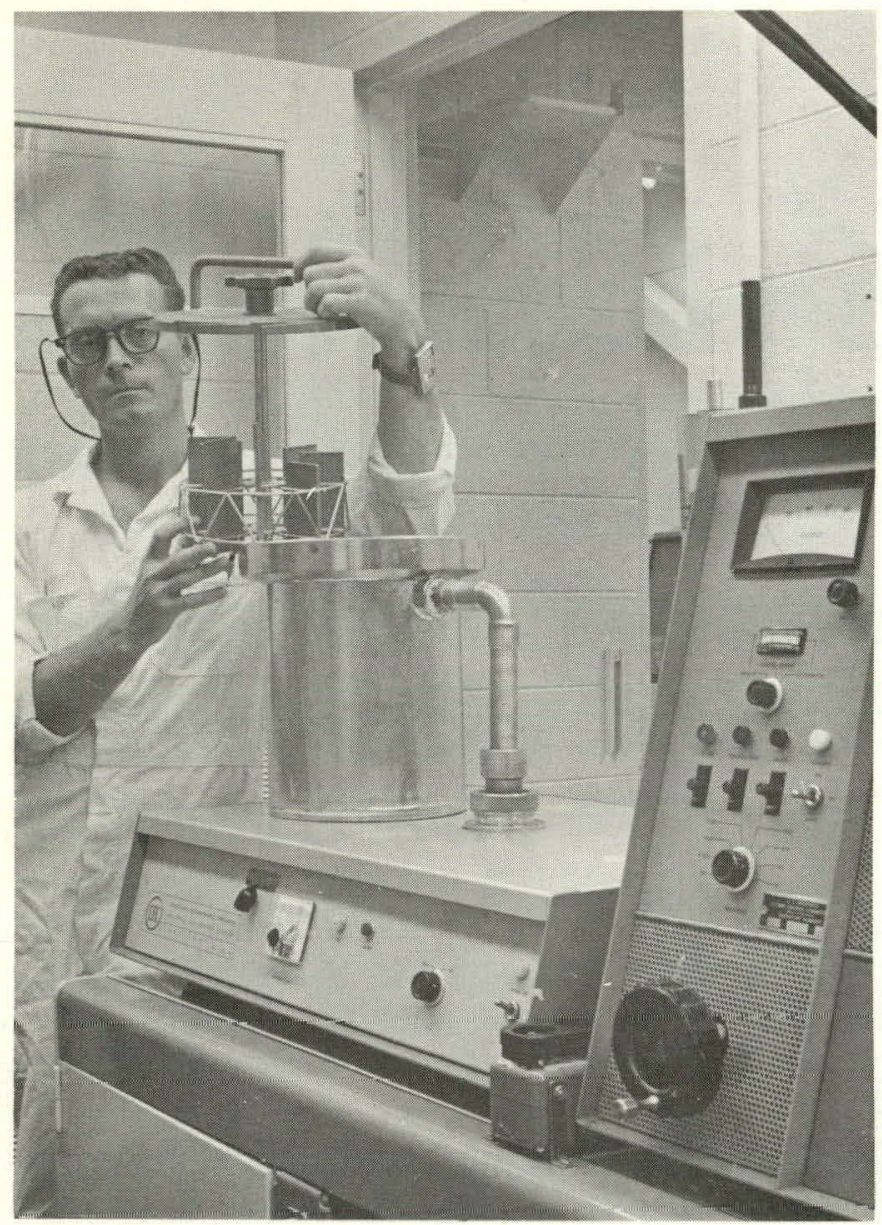

FIGURE 15. Leak-Test Chamber.

FIGURE 16. Bubble Leak-Test Chamber.

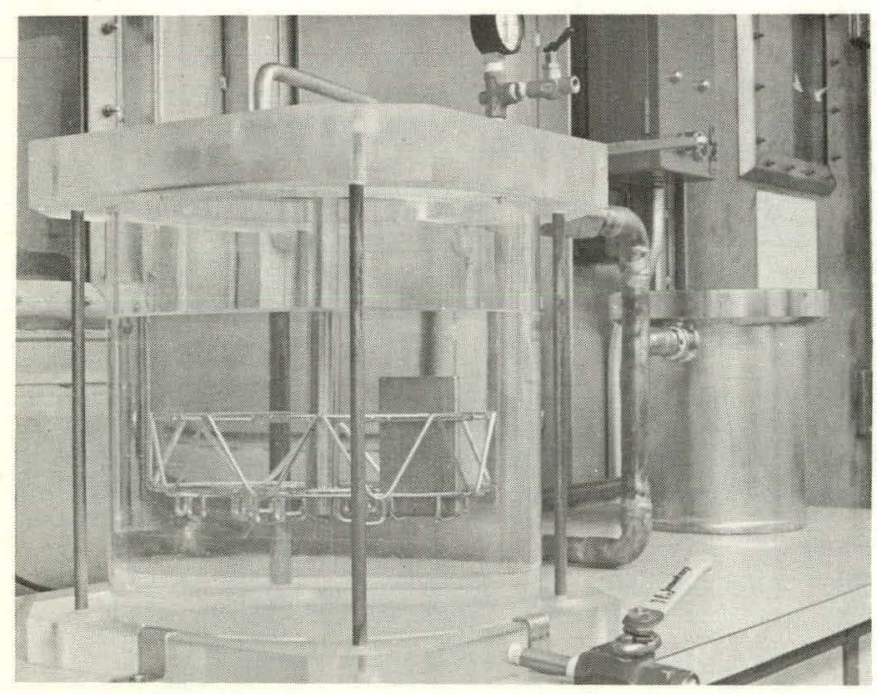

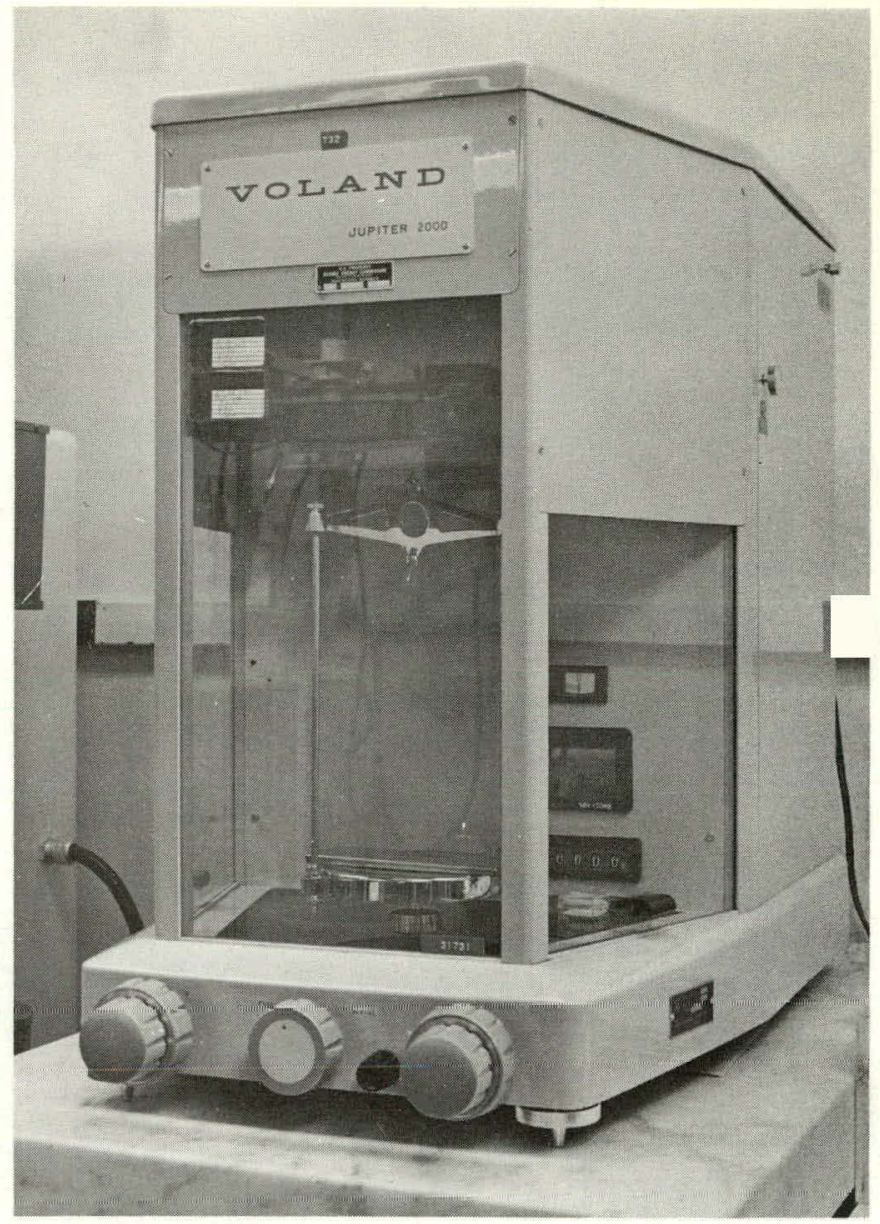

FIGURE 17. Volảnd Jupitcr-2000 Balance.

FIGURE 18, Counting Equipment.

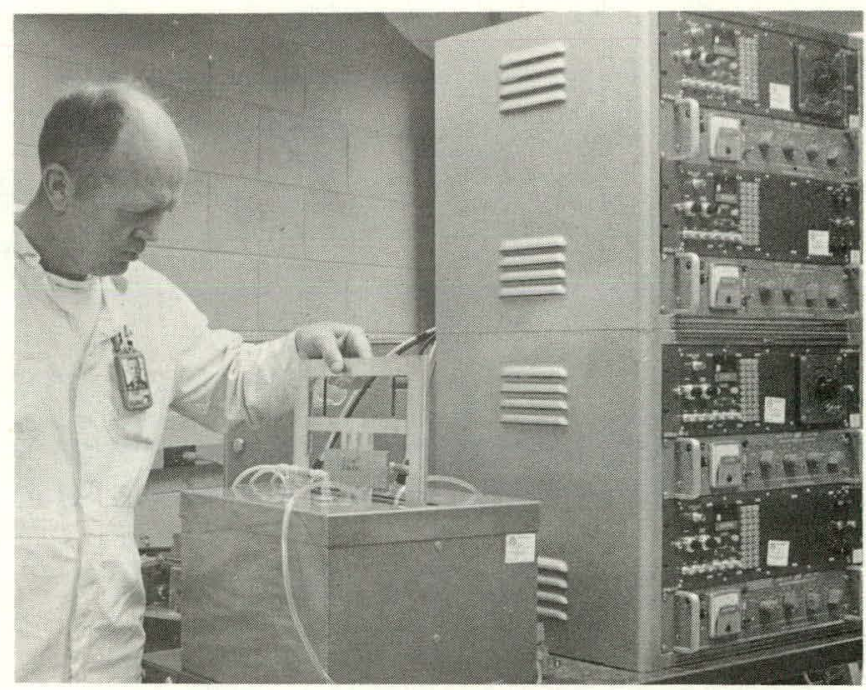

